\section{Quantum dots nanoparticle- based lateral flow assay for rapid detection of Mycobacterium species using anti-FprA antibodies}

\author{
Fabio Cimaglia, ${ }^{1,2}$ Alessandro Aliverti, ${ }^{3}$ \\ Maurizio Chiesa, ${ }^{1}$ Palmiro Poltronieri, ${ }^{2}$ \\ Enrico De Lorenzis, ${ }^{1}$ Angelo Santino, ${ }^{2}$ \\ Leonardo A. Sechi ${ }^{4}$
}

'Biotecgen, Lecce; 'Institute of Sciences of Food Production C.N.R. Unit of Lecce; ${ }^{3}$ University of Milan, Department of Biomolecular Sciences and Biotechnology, Milano; ${ }^{4}$ University of Sassari, Department of Biomedical Science, Sassari, Italy

\section{Abstract}

A lateral flow (LF) device combined with quantum dots (QDs) technology was developed for rapid detection of a specific mycobacterial flavoprotein reductase $(f p r A)$. In order to develop the LF assay based on a double-antibody sandwich format, two monoclonal antibodies recognizing different epitopes located in separated $f p r A$ domains were identified. The first monoclonal antibody was immobilized onto the detection zone of a porous nitrocellulose membrane, whereas another monoclonal antibody was conjugated to QDs nanoparticles as a detection system. Using these monoclonal antibodies we recorded a good fluorescence signal, the intensity of which was directly proportional to the concentration of $f p r A$ protein. The use of antibodies conjugated with fluorescent semiconductor QDs via biotin-streptavidin bridge, allowed the detection of $f p r A$ protein at concentrations as low as $12.5 \mathrm{pg} / \mu \mathrm{L}$ in less than $10 \mathrm{~min}$. The reported technology could be useful in the diagnostic investigation of Mycobacterium tuberculosis and other human pathogens in clinical specimens.

\section{Introduction}

In the past few years, the LF immunoassaybased technology has become a powerful tool in the rapid detection of pathogens in liquid samples. ${ }^{1}$

Originally this technique was used as a pregnancy test but nowadays several kits based on LF technology have been developed for a large number of pathogens, toxins or drugs. ${ }^{2-8} \mathrm{LF}$ technology provides qualitative information on the presence/absence of an analyte in a liquid sample with several advantages, including reduced time, low cost and possibility of performing on field assays, thus avoiding any sample transport. ${ }^{1}$ All these features make LF technology an interesting tool for diagnostic investigation of Mycobacterium tuberculosis. The last decade has seen a dramatic resurgence in the incidence of tuberculosis and related mycobacterial diseases, especially in poorer areas but also in developed world. ${ }^{9}$ Indeed, diagnosis of mycobacterial infections requires rapid assays for immediate therapy or treatments for disease prevention. ${ }^{10}$ Diagnostic investigations of mycobacterial infection are currently mostly based on microscopic analysis via the Ziehl-Neelsen or Auramine-rodhamine staining and culture isolation. ${ }^{11}$ Even though microscopic investigations are relatively rapid, they have several disadvantages in term of sensitivity and specificity. In fact, the microscopic analyses show a detection limit as low as $10^{5}$ bacilli/mL and only provide information on the presence of acid-alcohol resistant bacilli. ${ }^{10-12}$ Culture-based methods remain the gold standard even though the growth is slow and it may take 6-8 weeks. $^{13}$ Substantial shortening of detection time was realized by use of automated systems based on liquid culture, such as the BATEC radiometric method, Septicheck AFB and MIGIT fluorimetric method. ${ }^{14,15}$ These methods are able to reduce the time of diagnosis to 1-2 weeks but require dedicated extremely expensive equipment. DNA amplification techniques and high-performance liquid chromatography provide rapid analyses but require specialized personnel and are difficult to be implemented in clinical settings. ${ }^{16-20}$ Many studies have focused on $M$. tuberculosis diagnosis based on antigen detection by immunebased tests, such as dot immunobinding assay, ${ }^{21}$ capture enzyme-linked immunosorbent assay (ELISA), ${ }^{22}$ and by latex agglutination assay. ${ }^{23}$

Several mycobacterial antigens, such as the $38 \mathrm{kDa}$ antigen, ${ }^{24} 30 \mathrm{kDa}$ antigen, ${ }^{25} 16 \mathrm{kDa}$ antigen, ${ }^{26}$ lipoarabinomannan (LAM) $,{ }^{27} \mathrm{~A} 60,{ }^{28}$ Mtb81, ${ }^{29} 55 \mathrm{kDa}$ antigen, ${ }^{22} 14 \mathrm{kDa}$ antigen, 19 $\mathrm{kDa}$ antigen,${ }^{30}$ and ESAT- $6,{ }^{31}$ have been characterized, purified and, in some cases, reported for a potential use in the detection of tuberculosis. ${ }^{21,22,32,33}$

Using a dot immunobinding assay, Sumi $e t$ $a .^{21}$ was able to detect a circulating mycobacterial antigen (14 kDa antigen) in cerebrospinal fluid at the lowest concentration of $100 \mathrm{ng} / \mathrm{mL}$, within $6 \mathrm{~h}$. An ELISA based method was suggested to detect lipoarabinomannan antigen (LAM) in human sputum samples. ${ }^{32}$ The author reported a detection limit of 1 $\mathrm{ng} / \mathrm{mL}$ using a purified antigen and a concentration of $10^{4} M$. tuberculosis whole cells per mL. Recently, using a Fast Dot-Enzyme-Linked Immunosorbent Assay (FD-ELISA), El-Masry et $a l .{ }^{33}$ reported a fast assay which can be applied
Correspondence: Cimaglia Fabio, Biotecgen, via Leuca 174, 73100 Lecce, Italy.

Tel. +39.334 .331 .8636 - Fax: +39.0832 .349659 .

E-mail: f.cimaglia@biotecgen.it

Key words: lateral flow, quantum dot, Mycobacterium tuberculosis, flavoprotein reductase $\mathrm{A}$.

Acknowledgments: the authors would like to thank Dr. Tiit Talpsep (Quattromed Ltd, Tartu, Estonia) for monoclonal antibody production. This work was performed within the context of the NANOMYC project that is supported by the EU (LSHB-CT-2007-036812).

Contributions: FC, principal investigator, design of lateral flow assay; MC, technical work and Biotecgen RTD supervisor; PP, quantum dot conjugation; EDeL, technician, lateral flow tests; AA, competence in mycobacterial infections. FprA mutant protein study; AS, protein biochemistry, lateral flow assay set up, critical review of the manuscript; LAS, competence in mycobacterial infections. Studies on recombinant FprA protein and critical review of the manuscript.

Conflicts of interests: the authors declare no conflicts of interests.

Received for publication: 28 October 2011. Revision received: 21 December 2011. Accepted for publication: 30 December 2011.

This work is licensed under a Creative Commons Attribution NonCommercial 3.0 License (CC BYNC 3.0).

(C) Copyright F. Cimaglia et al., 2012

Licensee PAGEPress srl, Italy

Nanotechnology Development 2012; 2:e5

doi:10.4081/nd.2012.e5

in the field for the detection of a $20 \mathrm{kDa}$ mycobacterium antigen in serum from patients with pulmonary tuberculosis. This method was able to detect $1.8 \mu \mathrm{g} / \mathrm{mL}$ of purified antigen as the lowest detectable concentration. Some of these rapid methods display high sensitivity but require expensive equipment, training of personnel for their completion and have not been sufficiently explored in clinical practice. Moreover this current markers are not able to differentiate latent and active tuberculosis disease. ${ }^{34}$ Among possible strategies to effectively identify the active pathogen metabolism is the enzyme involved in Fe2+ availability in Mycobacteria, such as the mycobacterial ferredoxin reductase $\mathrm{A}$ (fprA), which seems a promising target to pursue..$^{35} \mathrm{fprA}$ is an $\mathrm{NAD}(\mathrm{P}) \mathrm{H}$ - and FAD-binding reductase, structurally and evolutionarily related to adrenodoxin reductase. ${ }^{36}$ Two genes, structurally related to the ferredoxin-NADP+ reductase (FNR) protein family, the flavoprotein reductases $f p r A$ and $f p r B$, were identified in $M$. tuberculosis with the former cloned, 
expressed and purified. ${ }^{37} \mathrm{fprA}$ is involved in the pathogen metabolism and is thought to support the activity of several mycobacterial enzymes. ${ }^{38}$ Thus, fprA represents a potential target for antimycobacterial drugs and bacterial viability. In addition, the aminoacidic sequence of $f p r A$ is highly conserved in $M$. paratuberculosis, whereas, it differs in other mycobacteria species (M. leprae, M. avium). Due to these similarities, the detection of this protein could provide useful information about the presence and vitality of bacteria in clinical and environmental samples.

In the present work, we used a recombinant $f p r A$ protein to set up a rapid and easy method for diagnosis of Mycobacterium tuberculosis, based on the lateral flow immunochromatography. The rapidity of lateral flow assay was combined to the sensitivity provided by Cadmium Selenide Quantum Dots (QDs) technology. QDs are fluorescent semiconductor metal oxides with high fluorescence intensity and long photostability. ${ }^{39} \mathrm{QDs}$, unlike organic dyes, display different colors corresponding to their sizes with a single excitation wavelength. ${ }^{40}$

\section{Materials and Methods}

\section{Expression and purification of $F p r A$}

fprA recombinant protein was expressed and purified according to Fischer et al. ${ }^{37}$ by the University of Sassari, Department of Biomedical Science. Total genomic DNA was isolated from Mycobacterium tuberculosis (strain H37Rv) using the QIAamp DNA Kit (Quiagen cat. n. 51304). M. tuberculosis fprA sequence (Gene ID: 888839) was amplified from genomic DNA by PCR using the following oligonucleotide sequences: 5'-GCCATATGATGCGTCCCTATTACA-3' and 5'-GTCATATGTCAGCCGAGCCCAAT-3', which contained the Nde I restriction sites (underlined), for subsequent cloning of $F p r A$ open reading frame into the pET-11a vector (Novagen cat. n. 69436-3), according to the procedure described by the supplier. E. coli BL21(DE3) cells were transformed with pET-FprA plasmid and the recombinant FprA protein was expressed and purified as described by Fischer et al. ${ }^{37}$

\section{Production of monoclonal antibodies against $F p r A$}

In order to produce monoclonal antibodies against the recombinant $f p r A$, mice were injected intraperitoneosly with $200 \mu \mathrm{l}$ of antigen (Ag). The immunization scheme was as follows:

$30 \mu \mathrm{g}$ of antigen were injected at day 0,30 , 60 and 90 , followed by a rest period of approximately 8-14 weeks for maturation to obtain antibodies with high affinity. Boosting was performed with $30 \mu \mathrm{g}$ of antigen in phosphatebuffered saline (PBS: $10 \mathrm{mM}$ phosphate, 150 $\mathrm{mM} \mathrm{NaCl}, \mathrm{pH}$ 7.5). Hybridoma cell clones were developed in 7-18 days as described by Leid $e t$ $a l^{41}$ and were screened by ELISA test against fprA. Eight clones were selected: 5B8.1; 5G10; $3 \mathrm{~A} 10 ; 2 \mathrm{~B} 12 ; 1 \mathrm{~A} 7.1 ; 2 \mathrm{G} 4 ; 4 \mathrm{H} 9$, and 4E8. The monoclonal antibodies were produced by Quattromed Ltd. (Tartu, Estonia).

\section{Antibody QD conjugation}

The monoclonal antibodies were desalted by gel filtration with Zeba ${ }^{\mathrm{TM}}$ Desalt Spin Columns (Pierce, cat. n. 89883). The antibodies were biotinylated using the biotin-XX microscale protein Kit (Molecular Probes ${ }^{\mathrm{TM}}$ cat. no. B30010) according to the procedure described by the supplier. The concentration of the biotinylated antibody was determined at 280 nm by a NanoDrop ND-1000 spectrophotometer (NanoDrop Technologies, Inc.). Cadmium selenide (CdSe) QDs (15-20 nm in size) with a maximum emission wavelength of $565 \mathrm{~nm}$, shelled with $\mathrm{ZnS}$ and coupled to streptavidin, were purchased by Invitrogen (Invitrogen cat. n. Q10131MP). The amount of $1 \mu \mathrm{L}$ of QDs 565 streptavidin conjugate was used to label $200 \mathrm{ng}$ of biotinylated antibody in PBS.

\section{Direct LF assay}

Hi Flow plus HF135 membrane sheet (Millipore cat. n. HF13502XSS) was cut into 0.6-0.7 $\mathrm{cm}$ wide and 6-7 $\mathrm{cm}$ long strips. The proteins were first desalted by gel filtration with $\mathrm{Zeba}^{\mathrm{TM}}$ Desalt Spin Columns and diluted in PBS before immobilization onto a strip. The LF test device was prepared as follows (Figure 1A): $1.5 \mu \mathrm{L}$ of $f p r A$ recombinant protein ( 0.5 $\mu \mathrm{g} / \mu \mathrm{L})$ was spotted on the membrane as test line and $1.5 \mu \mathrm{L}$ of Protein A ( $1 \mathrm{mg} / \mathrm{mL}$, Sigma) was spotted as control line. A distance of $1 \mathrm{~cm}$ was chosen between the test and control lines. After protein spotting, the membrane was dried at $37^{\circ} \mathrm{C}$ for $2 \mathrm{~h}$ and then assembled on a glass adhesive backing to provide rigidity. Cellulose sheet (Millipore cat. n. CFSP173000) was cut into $0.6-0.7 \mathrm{~cm}$ wide and $4-5 \mathrm{~cm}$ long sections and used as sample and adsorbent pad, respectively applied at the origin of the sample flow and at the end of the membrane, overlapping with a 0.4-0.7 cm membrane. One $\mu \mathrm{L}$ of monoclonal antibody conjugated with QDs (conjugated clone $4 \mathrm{H} 9$ at the concentration of $0.2 \mathrm{mg} / \mathrm{mL}$ ) was loaded onto the sample pad of the lateral flow and then one end of the strip was immediately dipped in a tube containing the running buffer, allowing the migration, by capillary forces, along the dipstick into the adsorbent pad. A positive result was visualized in less than 10 min by the appearance of two fluorescent lines, both in the test and in the control area, on a UV lamp (Gel Doc 1000, Biorad).

\section{Screening the better performing antibodies}

Several different monoclonal antibodies (clones: 5B8.1; 5G10; 3A10; 2B12; 1A7.1; 2G4; $4 \mathrm{H} 9$ and $4 \mathrm{E} 8$ ) were used as capture probe and immobilized onto the test lines of the nitrocellulose strip (two antibodies per strip). The LF test assay was performed as follows: $1 \mu \mathrm{L}$ of the QD conjugated antibody (conjugated clone $4 \mathrm{H} 9$ at the concentration of $0.2 \mathrm{mg} / \mathrm{mL}$ ) was incubated with $500 \mathrm{ng}$ of $\mathrm{fprA}$ recombinant protein and the mixture was assayed on LF strips.

\section{LF sandwich assay}

The lateral flow Assay based on double-antibody sandwich format was prepared immobilizing $1.5 \mu \mathrm{L}$ of the monoclonal antibody $(1 \mathrm{mg} / \mathrm{mL})$ raised against the $f p r A$ recombinant protein on the test lines. The LF test assay was performed as follows (Figure 1B): $200 \mathrm{ng}$ of the QD conjugated antibody (clone 4H9) was incubated with $f p r A$ recombinant protein in a final volume of $40 \mu \mathrm{L}(0.2 \%$ Tween- $20,0.2 \%$ BSA in PBS pH 7.4). After 15 min incubation at room temperature, the mixture was applied onto the sample pad of the LF and then the bottom tip of the strip was immediately dipped in the running buffer, allowing the migration along the dipstick into the adsorbent pad.

The result of the test was evaluated visually after $10 \mathrm{~min}$ by the UV lamp and the intensity of the test zone was estimated densitometrically using the software UN-SCAN-IT ${ }^{\mathrm{TM}}$ (Silk Scientific Inc.).

\section{Results and Discussion}

Direct LF assays were performed in order to check the best experimental conditions based on general protocols (Figure 1A).

Several different running buffers were tested for the optimum separation of protein complexes along the membrane, the ability to avoid non-specific adsorption of QDs onto the nitrocellulose strip, and for maintaining an appropriate $\mathrm{pH}$ for physiological stability of QD conjugated antibodies.

We also tested different combinations of three detergents, namely Triton X-100, Tween 20 and SDS, BSA and glycine, for reduce nonspecific adsorption and improved protein stability and solubility. The best results in terms of optimal flow rate and sensitivity were found using a running buffer consisting of PBS containing 1.5\% BSA and 3\% Tween-20 (Figure 2D). Lower or higher concentration of Tween-20 gave high background (Figure 2A) and fainter fluorescent signals (Figure 2B, C and E).

In order to perform the LF assay based on double-antibody sandwich format (Figure 1B), 
the binding ability of antibodies directed to different fprA domains was screened.

For this purpose, some different monoclonal antibodies (clones: 5B8.1; 5G10; 3A10; 2B12; $1 \mathrm{~A} 7.1 ; 2 \mathrm{G} 4 ; 4 \mathrm{H} 9$ and $4 \mathrm{E} 8$ ) were used as capture probe and immobilized onto the test lines of the nitrocellulose strip (two antibodies per strip). 4H9 was QD conjugated and chosen as detection antibody. The $2 \mathrm{G} 4$ antibody showed the highest fluorescence intensity in comparison with other antibodies used as capture probe. Good but weaker signals were also recovered form $5 \mathrm{G} 10$ and $2 \mathrm{~B} 12$ antibodies (Figure 3).
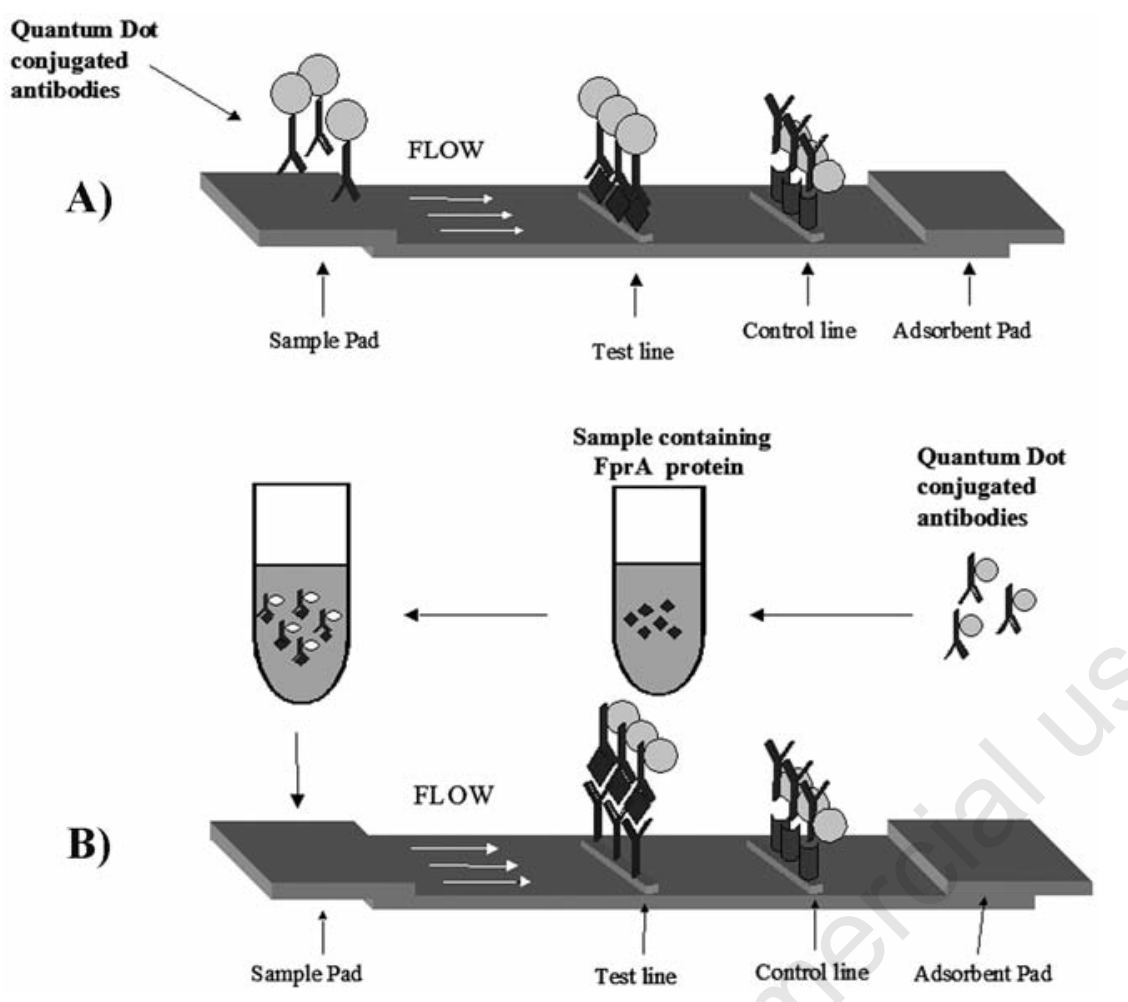

Figure 1. Schematic description of immunochromatographic test. (A) Direct lateral flow assay: QD conjugated antibody solution is applied onto the sample pad of the LF strip, containing on the test line the $f p r A$ recombinant protein and on the control line the Protein A. (B) Lateral flow assay based on double-antibody sandwich format: QD conjugated antibodies are incubated with the sample and then applied onto the sample pad of the LF strip. The complex QD conjugated antibody-protein is captured on the test line, by the immobilized antibodies and the excess of QD conjugated antibodies are captured on the control line, by the immobilized Protein A.

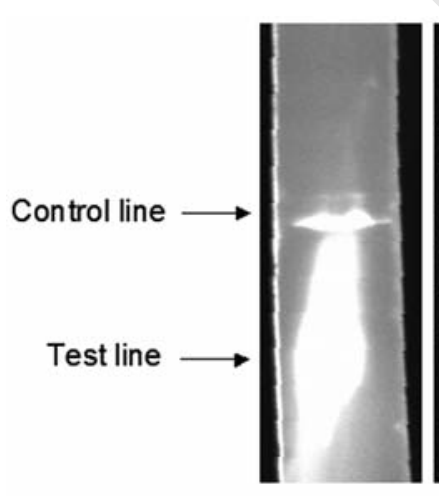

A

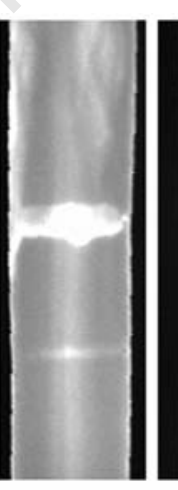

$\mathrm{B}$

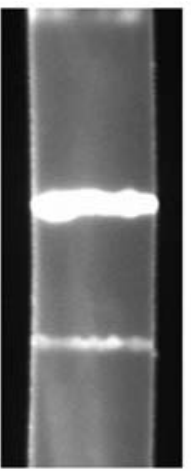

C

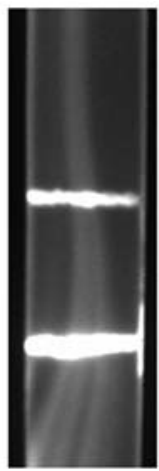

$\mathrm{D}$

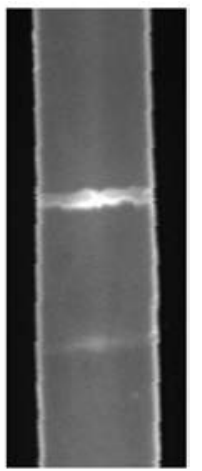

$\mathrm{E}$

Figure 2. Lateral flow device setup was carried out using the following running buffers: PBS+BSA +(A) $0.5 \%$ Tween-20; (B) 1\% Tween-20; (C) 2\% Tween-20; (D) 3\% Tween-20; (E) $4 \%$ Tween-20.

The sensitivity of the LF assay was later determined. Two hundred ng of QD conjugated $4 \mathrm{H} 9$ antibody was incubated with $0.05,0.5$, 5,50 and $500 \mathrm{ng}$ of $f p r A$ recombinant protein in a final volume of $40 \mu \mathrm{l}(0.2 \%$ Tween- 20 , $0.2 \%$ BSA in PBS) to obtain a final concentration of $1.25 \mathrm{pg} / \mu \mathrm{L}, 12.5 \mathrm{pg} / \mu \mathrm{L}, 125 \mathrm{pg} / \mu \mathrm{L}, 1.25$ $\mathrm{ng} / \mu \mathrm{L}$ and $12.5 \mathrm{ng} / \mu \mathrm{L}$, respectively. After incubation at room temperature for $15 \mathrm{~min}$, the mixtures were subjected to chromatographic separation onto LF strips, containing the antibody $2 \mathrm{G} 4$ in the test line and Protein A in the control line.

The minimum concentration of fprA protein, visually detectable on UV lamp, was 125 $\mathrm{pg} / \mu \mathrm{L}$ (Figure $4 \mathrm{~A}$ ); however, the densitometric analysis of the test zones allowed the detection limit to be lowered to $12.5 \mathrm{pg} / \mu \mathrm{L}$ (Figure 4B).

\section{Conclusions}

We describe a method based on lateral flow immunochromatographic assay and quantum dot labeled antibodies as fluorescent tracers. The device was developed to detect $M$. tuberculosis fprA proteins in liquid samples. In this experimental condition it was possible to detect the $f p r A$ protein at the lowest dilution of $12.5 \mathrm{pg} / \mu \mathrm{L}$.

The use of quantum dot labeled antibodies improved the sensitivity of lateral flow immunochromatographic assay compared to other immune-based tests such as ELISA ${ }^{32,33}$ and dot immunobinding assay. ${ }^{21}$ However, the major advantages of the LF are its speed (results may be available within $15 \mathrm{~min}$ ) and simplicity.

The lateral flow set up in this work showed the potential to be used as an assay method for detecting the presence of mycobacterial proteins. The LF device is versatile and could be implemented with additional antibodies to detect several mycobacterial antigens important in clinics, such as the $38 \mathrm{kDa}$ antigen, ${ }^{24} 30$ $\mathrm{kDa}$ antigen, ${ }^{25} 16 \mathrm{kDa}$ antigen, ${ }^{26}$ lipoarabinomannan (LAM), ${ }^{27} \mathrm{~A} 60,{ }^{28} \mathrm{Mtb} 81,{ }^{29} 55 \mathrm{kDa}$ antigen, ${ }^{22} 14 \mathrm{kDa}$ antigen, $19 \mathrm{kDa}$ antigen, ${ }^{30}$ and ESAT-6. ${ }^{31}$

In fact, the possibility of using antibodies conjugated with various QDs makes this technology suitable for multiplexing, allowing the detection of different antigens in one LF assay. ${ }^{42}$ Further work is required in order to validate the antibodies cross-reactivity towards different fprA proteins from Mycobacterium $s p p$. If the diagnostic value of $f p r A$ protein is confirmed, efforts should be focused on the clinical sample processing, in order to obtain the best exposure of $f p r A$ protein in the lateral flow assay. 


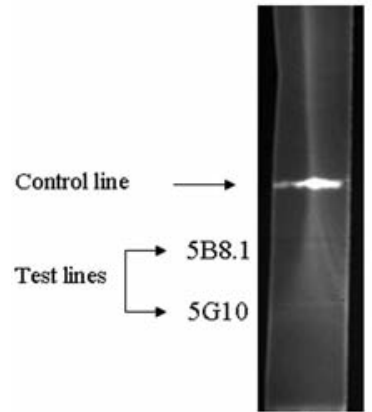

1

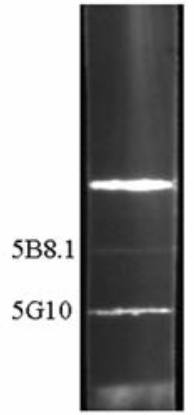

2

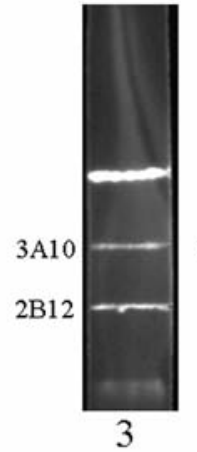

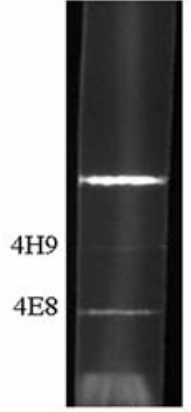

5

Figure 3. Lateral flow assay based on double-antibody sandwich format. Different monoclonal antibodies (clones: 5B8.1; 5G10; 3A10; 2B12; 1A7.1; 2G4; 4H9 and 4E8) were immobilized onto the test lines of the nitrocellulose strip (two antibodies per strip). Protein A was immobilized on the control line. The sample pad was loaded with QD conjugated antibody (clone $4 \mathrm{H} 9$ ) previously incubated with $f p r A$ recombinant protein (Lanes 2-5). As a negative control, QD conjugated antibody was incubated with BSA (Lane 1).

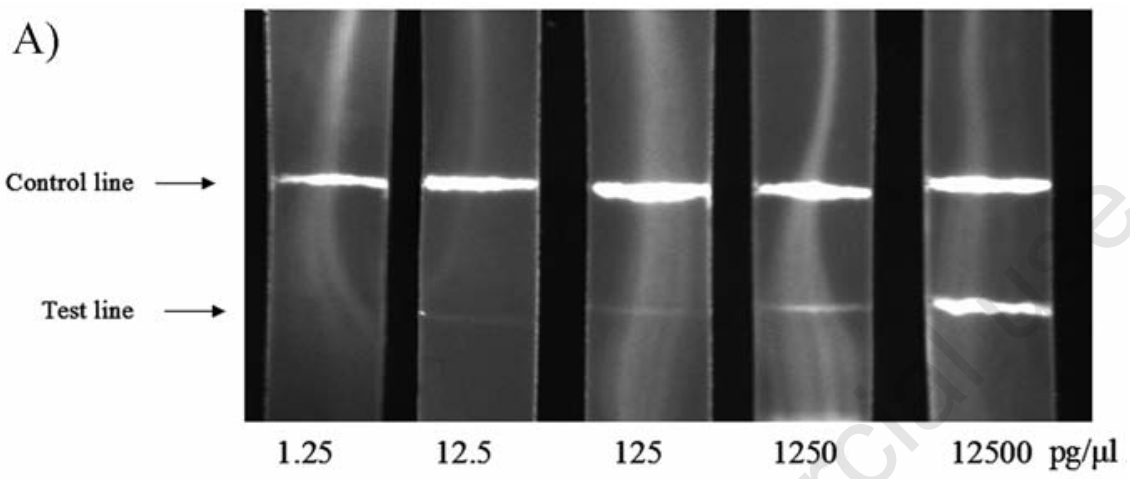

B)

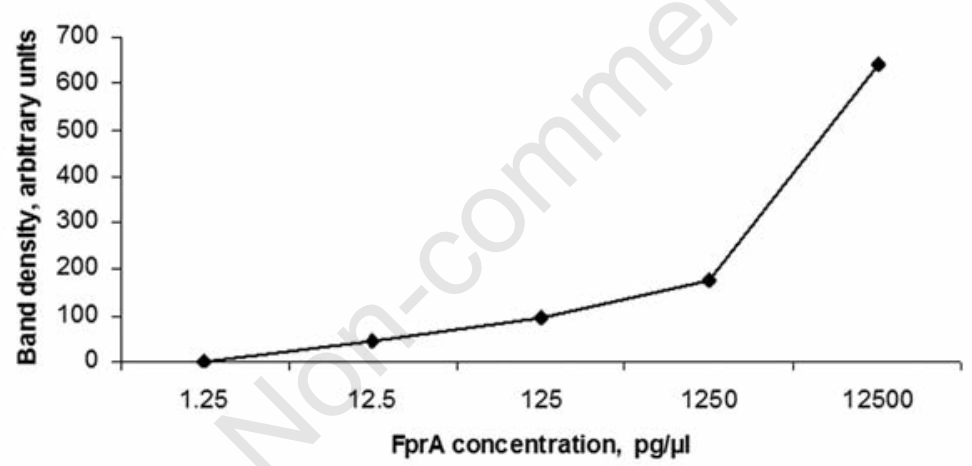

Figure 4. LF strips were tested for sensitivity using decreasing concentrations of $f p r A$ antigens. (A) QD conjugated $4 \mathrm{H} 9$ antibody was incubated with increasing concentration of fprA recombinant protein, ranging from 1.25 to $12500 \mathrm{pg} / \mu \mathrm{L}$, and assayed onto a $\mathrm{LF}$ strip device containing on the test line the capture antibody $2 \mathrm{G} 4$ and on the control line the Protein A. (B) Densitometric analysis of the test zones of the strip. The density of the test zone was plotted against the concentration of $f p r A$ protein loaded on the strip.

\section{References}

1. Posthuma-Trumpie GA, Korf J, van Amerongen A. Lateral flow (immuno)assay: its strengths, weaknesses, opportunities and threats. A literature survey. Anal Bioanal Chem 2009;393:569-82.

2. Al-Yousif Y, Anderson J, Chard-Bergstrom C, Kapil S. Development, evaluation, and application of lateral-flow immunoassay (immunochromatography) for detection of rotavirus in bovine fecal samples. Clin Diagn Lab Immunol 2002;9:723-5.

3. Cho YJ, Lee DH, Kim DO, et al. Production of a monoclonal antibody against ochratoxin A and its application to immunochromatographic assay. J Agric Food Chem 2005;53:8447-51.

4. Fisher M, Atiya-Nasagi Y, Simon I, et al. A combined immunomagnetic separation and lateral flow method for a sensitive onsite detection of Bacillus anthracis spores-assessment in water and dairy products. Lett Appl Microbiol 2009;48:413-18.

5. Kolosova AY, Sibanda L, Dumoulin F, et al. Lateral-flow colloidal gold-based immunoassay for the rapid detection of deoxynivalenol with two indicator ranges. Anal Chim Acta 2008;616:235-44.

6. Nielsen K, Yu WL, Lin M, et al. Prototype single step lateral flow technology for detection of avian influenza virus and chicken antibody to avian influenza virus. J Immunoassay Immunochem 2007;28: 307-18.

7. Posthuma-Trumpie GA, Korf J, van Amerongen A. Development of a competitive lateral flow immunoassay for progesterone: influence of coating conjugates and buffer components. Anal Bioanal Chem 2008;392:1215-23.

8. Shyu RH, Tang SS, Chiao DJ, Hung YW. Gold nanoparticle-based lateral flow assay for detection of staphylococcal enterotoxin B. Food Chemistry 2010;118:462-6.

9. Corbett EL, Watt CJ, Walker N, et al. The growing burden of tuberculosis. Global trends and interactions with the HIV epidemic. Arch Intern Med 2003;163:1009-21.

10. Källenius G, Hoffner SE, Miörner H, Svenson SB. Novel approaches to the diagnosis of mycobacterial infections. Eur Respir J 1994;7:1921-4.

11. Annam V, Kulkarni MH, Puranik RB. Comparison of the modified fluorescent method and conventional Ziehl-Neelsen method in the detection of acidfast bacilli in lymphnode aspirates. Cytojournal 2009;6:13.

12. Johansen IS. Rapid diagnoses of mycobacterial diseases, and their implication on clinical management. Dan Med Bull 2006;53:28-45.

13. De Lisle GW, Bengis RG, Schmitt SM, 0'Brien DJ. Tuberculosis in free-ranging wildlife: detection, diagnosis and management. Rev Sci Tech 2002;21:317-34.

14. Cummings DM, Ristroph D, Camargo EE, et al. Radiometric detection of the metabolic activity of Mycobacterium tuberculosis. J Nucl Med 1975;16:1189-91.

15. Watterson SA, Drobniewski FA. Modern laboratory diagnosis of mycobacterial infections. J Clin Pathol 2000;53:727-32.

16. Brisson NA, Aznar C, Chureau C, et al. Diagnosis of tuberculosis by DNA amplification in clinical practice evaluation. Lancet 1991;338:364-6.

17. Cousins DV, Wilton SD, Francis BR, Gow BL. Use of polymerase chain reaction for rapid diagnosis of tuberculosis. J Clin Microbiol 1992;30:255-8.

18. Glickman SE, Kilburn JO, Butler WR, 
Ramos LS. Rapid identification of mycolic acid patterns of mycobacteria by highperformance liquid chromatography using pattern recognition software and a Mycobacterium library. J Clin Microbiol 1994;32:740-5.

19. Pandey J, Talib VH. Laboratory diagnosis of tuberculosis: use of ELISA and PCR. Indian J Pathol Microbiol 1993;36:512-8.

20. Ravva SV, Stanker LH. Real-time quantitative PCR detection of Mycobacterium avium subsp. paratuberculosis and differentiation from other mycobacteria using SYBR Green and TaqMan assays. J Microbiol Methods 2005;63:305-17.

21. Sumi MG, Mathai A, Sarada C, Radhakrishnan V. Rapid diagnosis of tuberculous meningitis by a dot immunobinding assay to detect mycobacterium antigen in cerebrospinal fluid specimens. J Clin Microbiol 1999;37:3925-7.

22. Attallah AM, Osman S, Saad A, et al. Application of a circulating antigen detection immunoassay for laboratory diagnosis of extra-pulmonary and pulmonary tuberculosis. Clin Chim Acta 2005;356:58-66.

23. Krambovitis E, McIllmurray MB, Lock PE, et al. Rapid diagnosis of tuberculous meningitis by latex particle agglutination. Lancet 1984;2:1229-31.

24. Andersen AB, Hansen EB. Structure and mapping of antigenic domains of protein antigen b, a 38,000 molecular-weight protein of Mycobacterium tuberculosis. Infect Immun 1989;57:2481-8

25. Salata RA, Sanson AJ, Malhotra IJ, et al. Purification and characterization of the 30,000 kilodalton native antigen of $\mathrm{M}$. tuberculosis and characterization of six monoclonal antibodies reactive with a major epitope of this antigen. J Lab Clin Med 1991;118:589-98.
26. Verbon A, Hartskeeri RA, Moreno C, Kolk AH. Characterization of B cell epitopes on the $16 \mathrm{~K}$ antigen of Mycobacterium tuberculosis. Clin Exp Immunol 1992;89:395401.

27. Hunter SW, Gaylord H, Brennan PJ. Structure and antigenicity of the phosphorylated lipopolysaccharide antigens from the leprosy and tubercle bacilli. J Biol Chem 1986;261:12345-51.

28. Cocito C, Vanlinden F. Preparation and properties of antigen 60 from Myco-bacterium bovis BCG. Clin Exp Immunol 1986;66:262-72.

29. Hendrickson RC, Douglass JF, Reynolds LD, McNeill PD. Mass spectrometric identification of Mtb 81, a novel serological marker for tuberculosis. J Clin Microbiol 2000;38:2354-61.

30. Jackett PS, Bothamley GH, Batra HV, et al. Specificity of antibodies to immunodominant mycobacterium antigens in pulmonary tuberculosis. J Clin Microbiol 1988;26:2313-18.

31. Arend SM, Ottenhoff THM, Andersen P, van Dissel JT. Uncommon presentation of tuberculosis: the potential value of a novel diagnostic assay based on the Mycobacterium tuberculosis-specific antigens ESAT-6 and CPF-10. Int J Tuberc Lung Dis 2001;5:680-6.

32. Pereira Arias-Bouda LM, Nguyen LN, Ho LM, et al. Development of antigen detection assay for diagnosis of tuberculosis using sputum samples. J Clin Microbiol 2000;38:2278-83.

33. El-Masry S, El-Kady I, Zaghloul MH, AlBadrawey MK. Rapid and simple detection of a mycobacterium circulating antigen in serum of pulmonary tuberculosis patients by using a monoclonal antibody and FastDot-ELISA. Clin Biochem 2008;41:145-51.
34. Metcalfe JZ, Everett CK, Steingart KR, et al. Interferon- $\gamma$ release assays for active pulmonary tuberculosis diagnosis in adults in low- and middle-income countries: systematic review and meta-analysis. J Infect Dis 2011;204:1120-9.

35. Banerjee S, Farhana A, Ehtesham NZ, Hasnain SE. Iron acquisition, assimilation and regulation in mycobacteria. Infect Genet Evol 2011;11:825-38.

36. Sabri M, Dunford AJ, McLean KJ, et al. Characterization of coenzyme binding and selectivity determinants in Mycobacterium tuberculosis flavoprotein reductase A: analysis of $\operatorname{Arg}(199)$ and $\operatorname{Arg}(200)$ mutants at the $\mathrm{NADP}(\mathrm{H}) 2$ '-phosphate binding site. Biochem J 2009;417:103-12.

37. Fischer F, Raimondi D, Aliverti A, Zanetti G. Mycobacterium tuberculosis fprA, a novel bacterial NADPH-ferredoxin reductase. Eur J Biochem 2002;269:3005-13.

38. Terwilliger TC, Park MS, Waldo GS, et al. The TB structural genomics consortium: a resource for Mycobacterium tuberculosis biology. Tuberculosis (Edinb) 2003;83:22349.

39. Guo P, Wei C. Quantum dots for robust and simple assays using single particles in nanodevices. Nanomedicine 2005;1:12224.

40. Goldman ER, Medintz IL, Mattoussi H. Luminescent quantum dots in immunoassays. Anal Bioanal Chem 2006;384:560-63.

41. Leid JG, Hunter D, Speer CA. Early diagnosis of Johne's disease in the American bison by monoclonal antibodies directed against antigen 85. Ann N Y Acad Sci 2002;969:66-72.

42. Goldman ER, Clapp AR, Anderson GP, et al. Multiplexed toxin analysis using four colors of quantum dot fluororeagents. Anal Chem 2004;76:684-8. 